\title{
Effect of parity on lactation traits in crossbred Holstein Friesian in Ethiopia
}

\author{
E.K. Senbeta* and A.S. Abebe
}

School of Animal and Range Sciences, Haramaya University, P.O. Box 138, Dire Dawa, Ethiopia

${ }^{*}$ Corresponding author e-mail: ewonetu2011@gmail.com, +25191292703, ORCiD: 0000-0002-3303-2194

Journal of Livestock Science (ISSN online 2277-6214) 12: 176-183

Received on 27/1/21; Accepted on 21/5/21; Published on 9/6/21

doi. 10.33259/JLivestSci.2021.176-183

\begin{abstract}
This study has assessed the effects of parity on lactation length, lactation milk yield, and lactation curves for each lactation stage at Haramaya University dairy research and teaching farm. Thirty-one synchronized Holstein Frisian crossbred heifers; with nearly similar age were selected and stall-fed for the whole lactation period. Data were collected on daily milk yield at each stage, days in milk and lactation milk yield, 305 days milk yield, and analyzed using the t-test for means. There was an insignificant effect on lactation length, total lactation milk yield, 305 days total milk yield, mid and late lactation milk yield between the $1^{\text {st }}$ and $2^{\text {nd }}$ lactation numbers. The rate of variation was very high (13.4\%) during the early lactation stage. The daily milk yield was significantly influenced by parity $(\mathrm{P}<0.05)$. The variation rate of milk yield in the morning milking was ranging from $10-51 \%$.Further study is required to examine additional aspects of parity on lactation traits such as milk composition and reproductive traits with more lactation numbers
\end{abstract}

Keywords: Crossbred cow; Lactation stages; Milk yield; Parity 


\section{Introduction}

Parity is one of the major sources of variation in milk yield and production increases from parity 1 to 3 after which it dropped (Epaphras et al., 2004). On the other hand, younger cows took longer to attain peak milk yield than older cows and this response seems to be because young cows are not physically mature (Coffey et al., 2006); when they are approaching their first lactation they are in a different metabolic state compared with that of multiparous cows because they require nutrients for their continued growth in addition to that of their udder development and milk synthesis (Wathes et al., 2007). Many studies on the effect of lactation number on milk yields of cows have been conducted and essentially all studies have demonstrated that milk production increases with lactation number and is maximized in the fourth or fifth lactation (Arbel et al., 2001). This is a result of the increasing development and size of the udder (Sorensen et al., 2006) with a consequent increase in the number of secretory cells (Dado and Allen, 1994). Other reasons for increased milk yield with increased parity are differences in the control of tissue mobilization between primiparous and multiparous cows (Wathes et al., 2007), different endocrine background at parturition in the less mature cows, which limits partitioning of nutrients into milk (Wathes et al., 2007), lower consumption of feed per day of primiparous cows than multiparous cows (Dado and Allen, 1994) and the increasing body size of older cows over that of first-lactation animals.

Primiparous cows had significantly longer lactation lengths than multiparous cows (Kashoma et al., 2015). The longer least-square means value for lactation length reflects that the cows were not allowed to dry off at the proper time and continued to milk for an extended period (Krishantan and Sinniah, 2014). Lactation length should not exceed the standard length of 305 for cattle breeds because it will increase the calving interval and decrease the number of calves that could be obtained during the life span of a cow (Krishantan and Sinniah, 2014). 80\% variations in milk yields of dairy cows were attributed to environmental factors and parity is among the non-genetic factors influencing lactation milk yield (Kashoma et al., 2015) and lactation length (Kumar et al.2014). Parity has also an effect on lactation pattern or curved shape that helps to identify feeding and management problems within a dairy herd (Epaphras et al., 2004). Little information is available on lactation traits and curves in Ethiopia. Moreover, the effect of parity on milk yield during different stages of lactation is not extensively studied. Therefore; the objective of this study was to assess the effects of parity on lactation length and pattern of milk yield for stall-fed crossbred Holstein Friesian cows.

\section{Materials and Methods Study area}

The study was conducted at Haramaya University dairy research farm, located at $505 \mathrm{~km}$ east of Addis Ababa and situated at an altitude of 1980 meter above sea level, $9^{\circ} 26^{\prime} \mathrm{N}$ latitude and $42^{\circ} 3^{\prime} \mathrm{E}$ longitude. The area has an average annual rainfall of $741.6 \mathrm{~mm}$. The mean annual minimum and maximum temperatures are $8.25{ }^{\circ} \mathrm{C}$ and 3.4 ${ }^{\circ} \mathrm{C}$, respectively.

\section{Study sample and methods}

Among synchronized Holstein Frisian crossbred heifers, thirty-one (31) with nearly similar age and first calvers were purposefully selected and stall-fed for the whole lactation of $1^{\text {st }}$ parity. Among the thirty-one cows naturally bred for the $2^{\text {nd }}$ parity, fourteen (14) cows that gave birth nearly in the same month for the $2^{\text {nd }}$ times were purposefully chosen and similarly managed for the whole lactation period.

\section{Animal management}

Animals were maintained under intensive systems. Cows were tied in a barn and individually fed at a rate of $0.5 \mathrm{~kg}$ per $1 \mathrm{~kg}$ of milk-based on the recommendation given by earlier scholars (Pandey and Voskuil, 2011). The feeds used were mixed on the farm, from grains or by-products such as wheat bran, soybean meal, peanut cake, ground maize, salt, and ruminant premix. Animals were fed the calculated amount of concentrate ration in three equal feedings every eight-hour intervals (at 7:00 am, 3:00 pm, and 17:00) whereas during the dry period animals were individually stall-fed $3 \mathrm{~kg}$ mixed concentrate feeds once every day at 8:00 am. During the entire day, drinking water was provided as ad libitum. All animals were fed hay in groups in the morning starting at 8:00 Am and corn silage in the afternoon starting at 1:00 pm as ad libitum. Animals were milked twice a day by a milking machine at 6:00 am and 6: $00 \mathrm{pm}$.

\section{Data collection}

Starting at seven days postpartum to the end of lactation, the daily milk yield of cows were individually recorded for the morning and afternoon milking separately using sensitive balance. At the end of each lactation, other data collected were lactation length, total lactation milk yield, 305 days milk yield, daily milk yield of lactation, daily milk yield of 305 days lactation, Early (7-100days), Mid (101-200 days) and Late (201-305 days) daily lactation milk yield. 


\section{Data handling and analysis}

Data entry and management were made using Microsoft Excel sheets and analyzed using the t-Test Paired for two samples for means tool performed to ascertain if the null hypothesis can be accepted or rejected. The least-square means comparison was performed using significance level at $(\mathrm{p}<0.05)$. The rate of variation in milk between first and second parity was calculated. The statistical model used during data analysis was: $Y_{i j}=\mu+P_{i}+e_{i j}$, Where: $Y_{i j}=$ Observation on parameters under consideration, $\mu=$ overall mean, $\mathrm{P}_{\mathrm{i}}=$ Effects of $\mathrm{i}^{\text {th }}$ parity, $\mathrm{e}_{\mathrm{ij}}=$ Random error

\section{Results and Discussion}

\section{Lactation length (LL)}

The overall mean of lactation length (Table 1) in this study is close to the optimal lactation length (305 days) generally agreed upon in the cow's calendar. The mean LL was shorter than the mean value of 366 in Pakistan (Usman et al., 2012), 332 in Sudan (Amasaib et al., 2008); 366.5 days under subtropical conditions (Usman et al., 2012) for Holstein Friesian cows, however; it was higher than $291.86 \pm 6.55$ days in Pakistan for the same breed (Sattar et al., 2005). Parity had no significant effect $(\mathrm{P}>0.05)$ on LL (Table 1) and this agreed to an earlier study that reported as lactation number has no significant effect on lactation duration (Erdem et al., 2007, Parineeta et al., 2017). In contrast, the effect of parity on LL $(\mathrm{P}<0.05)$ conformed to the findings reported in earlier study (Kumar et al.2014). In this report, the lactation duration for parity one is slightly higher than parity two and this is agreed to (Sattar et al., 2005) who reported the decrease of lactation lengths with an increase in parity. Whereas this study has disagreed with Wondossen et al. (2018) who reported slightly increased lactation length with an increase in parity of cow. Generally, the lactation duration observed in this study was in a similar range (284.7-333 days) reported in a previous study for Holstein cows (Erdem et al., 2007). The overall lactation length in this study is close to the optimum value of 305 days required to maintain the optimum calving interval of 12-13 months. This implied that animals on the farm are provided good management.

\section{Total lactation milk yield (TLMY)}

The overall mean TLMY was found in Table 1 and this is far above the value reported than 2772.76 litters (Sattar et al., 2005), 3438 (Usman et al., 2012) reported for Holstein Friesian cows in Ethiopia, India, Pakistan, and subtropical conditions, respectively. In contrast, it is by far less than 5519 (Kollalpitiya et al., 2012), 5468 (Amasaib et al. 2008) that reported in different countries for HF cows. This lower LMY of HF cows in this study might be due to the use of young cows in lactation which is in the $1^{\text {st }}$ and $2^{\text {nd }}$ parity. This is agreed to earlier studies that reported that first lactation cows produce approximately $75 \%$ of the milk produced by mature cows (Lateef et al., 2008). Parity had no significant difference $(\mathrm{P}>0.05)$ on LMY, however, it showed an increase of more than 157 liters (3.28\%) on average from lactation one to two. In contrast, (Metaxas, 2016) reported a large significant difference between the first and second lactation (+310 kg more in parity two). Besides, the significant effect of parity on LMY was reported in previous studies (Wondossen et al., 2018). Moreover, (Lateef et al., 2008) reported a non-significant difference existed between first and second lactations among Holstein Friesian cows. An increase in milk production from lactation one to two (+ 1000 liters more in parity two) in Holstein Friesian was also reported by (Amani et al., 2007). The overall mean milk yield per lactation for parity one and two in this study was higher than $3186.689 \pm 93.577$ and $3186.69 \pm 93.58$ for parity one and $3496.299 \pm 93.580$ and $3496.30 \pm 93.58$ for parity two in Sudan (Metaxas, 2016). Almost the same values of total lactation milk yield of 4729.5 and 4979.24 litters were reported for parity one and two, respectively (Kashoma et al., 2015). This study report conformed to Wondossen et al. (2018) who reported the lowest milk production in first lactation cows. As well, Kashoma et al. (2015) reported an increase in lactation milk yield with an increase in parity because mature cows use most of the nutrients for milk production and have the ability to gain body weight and condition quickly after calving whereas the first calvers face lactation stress and partition nutrients for continuous body growth and milk production. Dijkstra et al. (1997) also reported low milk yield in young cows due to underdeveloped udders and hence low alveoli activity, however, this improves with the age of an animal as a result of cell proliferation until a later age when the rate of cell death surpasses proliferation leading to a drop again in milk yield.

\section{Days total milk yield}

Parity had no significant effect ( $p>0.05$ ) on adjusted 305 days milk yield (Table1). This has concurred to a non-significant effect of lactation number on 305 days milk yield reported in previous studies (Kocak et al., 2007). Opposing this finding, earlier scholars reported the significant effect of lactation number on 305 days milk yield (Erdem et al., 2007). The overall 305 days total milk yield in this finding is almost the same as 4557 litters reported in Kenya (Ojango and Pollott, 2001) for 305 days milk yield. However, lower (2015 litters) of 305 days milk yield was reported for Holstein Friesian in Zimbabwe (Ngongoni et al., 2006). 


\section{Daily milk yield}

This study revealed a significant effect $(\mathrm{P}<0.05)$ of parity on the mean daily milk yield of lactation (Table 1). This is agreed to earlier study reports that depicted the significant influences of parity on daily milk yield (Bytyqi et al., 2009, Wondossen et al., 2018). However, the daily milk test on the standard lactation length (305 days) is not influenced by parity $(\mathrm{P}>0.05)$. In contrast, several scholars indicated the effect of parity $(\mathrm{P}<0.01)$ on 305 -day milk yield (Parineeta et al., 2017). This is probably due to the variation in lactation length besides other genetic and environmental factors. The results show that cows in the $2^{\text {nd }}$ lactation produce more milk compared to the $1^{\text {st }}$ (Table 1) and it disagrees with Bytyqi et al.(2009) who reported that cows in the first lactation produce more milk (18.43 $\mathrm{kg} /$ day) compared to the $2^{\text {nd }}(17.20), 3^{\text {rd }}(17.73), 4^{\text {th }}(16.91)$, and those in lactation $\geq 5^{\text {th }}(17.72 \mathrm{~kg} / \mathrm{day})$. The mean daily milk yield of lactation and 305 days obtained in this study (Table 1) for $1^{\text {st }}$ and $2^{\text {nd }}$ parity are higher than the results reported for $1^{\text {st }}(11.24), 2^{\text {nd }}(12.34), 3^{\text {rd }}(12.66)$, and $4^{\text {th }}(12.93 \mathrm{Kg} /$ day) $($ Metaxas, 2016). The overall mean daily milk yield of lactation and 305 days (Table 1) for Holstein Friesian cows are higher than the results reported Holstein Friesian breed, that is 13.15 in Sudan (Amasaib et al., 2008), 9.4 in Pakistan (Usman et al., 2012), 8.4 litters/day in Ethiopia (Belay et al., 2012), 13.2 in Egypt (36) whereas it is lower than 16.5 (Amasaib et al., 2008) and 16.7 liters/day (Ojango and Pollott, 2001) results reported in Sudan, Tunisia, and Kenya, respectively. This lower mean daily milk yield reported in this study might be due to the variation in lactation number/parity as this study evaluated data only for $1^{\text {st }}$ and $2^{\text {nd }}$ parity. Besides, variations in the genetic constitute of the cows, lactation length, and management given to the animals are among the major factors that contributed to the variation in daily milk yield.

Table 1 Effect of parity on lactation length and milk production

\begin{tabular}{|l|l|l|l|l|l|}
\hline Variables & $\begin{array}{l}\text { Parity } \\
(\mathbf{n}=32)\end{array}$ & $\begin{array}{l}\text { Parity } 2 \\
(\mathbf{n = 1 4})\end{array}$ & $\begin{array}{l}\text { Overall mean } \\
(\mathbf{n = 4 6})\end{array}$ & $\boldsymbol{P}$-value & SL \\
\hline Lactation length (days) & 322.38 & 304.08 & 313.23 & 0.385 & $\mathrm{NS}$ \\
\hline Total lactation milk yield (Kg/cow) & 4659.28 & 4817.27 & 4738.28 & 0.654 & $\mathrm{NS}$ \\
\hline 305 days total milk yield (Kg/cow) & 4318.91 & 4762.36 & 4550.64 & 0.165 & $\mathrm{NS}$ \\
\hline Daily milk yield of lactation (kg/cow) & $14.45^{\mathbf{b}}$ & $15.88^{\mathbf{a}}$ & 15.17 & 0.022 & $*$ \\
\hline Daily milk yield on 305 days lactation (Kg/cow) & 14.16 & 15.61 & 14.89 & 0.165 & $\mathrm{NS}$ \\
\hline Early lactation milk yield (7-100days) & $15.35^{\mathbf{b}}$ & $17.67^{\mathbf{a}}$ & 16.51 & 0.0019 & $* *$ \\
\hline Mid lactation milk yield (101-200 days) & 14.26 & 14.74 & 14.50 & 0.482 & $\mathrm{NS}$ \\
\hline Late lactation milk yield (201-305 days) & 12.40 & 11.73 & 12.07 & 0.339 & $\mathrm{NS}$ \\
\hline
\end{tabular}

$\mathrm{n}$ - Number of observations; NS-non significant,SL-Significant level

Table 2 Effect of parity on morning and afternoon milk yield

\begin{tabular}{|l|l|l|l|l|l|}
\hline Variables & Parity 1 & Parity 2 & Variation & P-value & SL \\
\hline Total morning lactation milk yield $(\mathrm{Kg} / \mathrm{cow})$ & 2426.80 & 2401.80 & -25.0 & 0.887 & $\mathrm{NS}$ \\
\hline Total afternoon lactation milk yield $(\mathrm{Kg} / \mathrm{cow})$ & 2083.40 & 1967.20 & -116.2 & 0.491 & $\mathrm{NS}$ \\
\hline 305 days total morning milk yield $(\mathrm{Kg} / \mathrm{cow})$ & 2235.50 & 2330.90 & 95.4 & 0.3531 & $\mathrm{NS}$ \\
\hline 305 days total afternoon milk yield $(\mathrm{Kg} / \mathrm{cow})$ & 1838.56 & 1948.48 & 109.92 & 0.2115 & $\mathrm{NS}$ \\
\hline Daily morning milk yield on 305 days lactation $(\mathrm{kg}) / \mathrm{cow}$ & 7.94 & 8.01 & 0.07 & 0.879 & $\mathrm{NS}$ \\
\hline Daily afternoon milk yield on 305 days lactation $(\mathrm{kg}) / \mathrm{cow}$ & 6.63 & 6.81 & 0.18 & 0.137 & $\mathrm{NS}$ \\
\hline Mean morning early milk yield (7-100days) $(\mathrm{kg}) / \mathrm{cow}$ & $8.19^{\mathrm{b}}$ & $9.26^{\mathrm{a}}$ & 1.07 & $<0.021$ & $*$ \\
\hline Mean morning mid milk yield $(101-200$ days) $(\mathrm{kg}) / \mathrm{cow}$ & 7.97 & 7.97 & 0.00 & 0.990 & $\mathrm{NS}$ \\
\hline Mean morning late milk yield $(201-305$ days) $(\mathrm{kg}) / \mathrm{cow}$ & 6.76 & 6.59 & -0.17 & 0.0504 & $\mathrm{NS}$ \\
\hline Mean afternoon early lactation milk yield (7-100days) & $7.22^{\mathrm{b}}$ & $8.20^{\mathrm{a}}$ & 0.98 & $<0.0187$ & $*$ \\
\hline Mean afternoon mid -lactation milk yield (101-200 days) & 6.32 & 6.74 & 0.42 & $<0.193$ & $\mathrm{NS}$ \\
\hline Mean afternoon late lactation milk yield (201-305 days) & 5.43 & 5.11 & -0.32 & 0.349 & $\mathrm{NS}$ \\
\hline
\end{tabular}

SL-Significant level; NS-non significant 


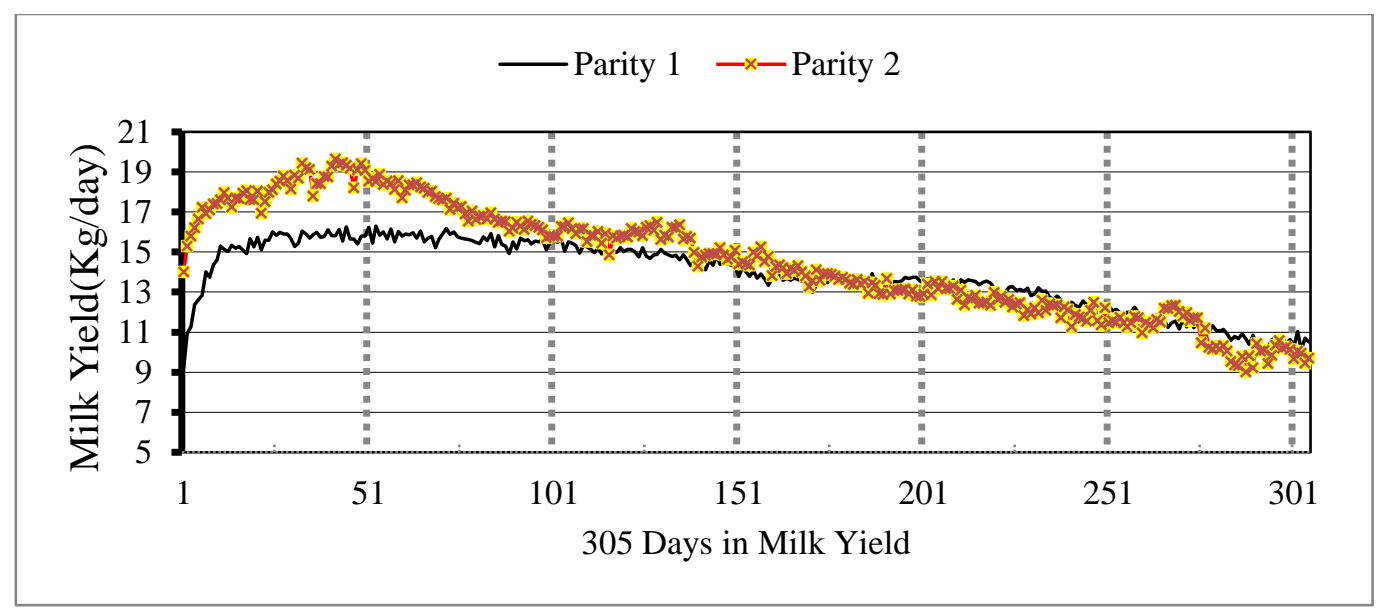

Figure 1. The pattern of milk yield through the lactation period

\section{Lactation stage and lactation curve}

This study revealed that there was a significant $(\mathrm{p}<0.01)$ difference between first and second parity during the first 100 days (Table 1). The mean daily milk yield during the early lactation for the $2^{\text {nd }}$ party is higher by 2.32 litters $(13.4 \%)$ than the daily mean milk yield for the $1^{\text {st }}$ parity. This agreed with Cho et al. (2016) who reported a difference between first and second parity as for stage of lactation. The pattern of mean daily milk production throughout the lactation period (Fig 1) and during the early lactation stage (Fig 2) indicated that first lactation cows have the lowest peak yields but the highest days in milk (DIM) at peak and more persistent than the second lactation cows. This is consistent with Rekika et al. (2003) who reported that first lactation cows have the lowest total and peak yields but the highest DIM at peak and persistency. Moreover, (Tekerli et al., 2000) reported as first lactation cows produce lower yields than older cows at the beginning of the lactation but more persistent. The rate of variation between the first and second parity (fig 5) is very high during the early lactation (13.4\%) and relatively low during the late lactation $(2.82 \%)$. This indicated that the significant difference $(\mathrm{P}<0.05)$ between parity 1 and 2 in mean daily milk yield per lactation (Table 1) is due to the high variation that comes from the early lactation. The higher total and daily milk yield in the second parity cows during the early lactation is since mature cows can gain body weight and condition quickly after calving whereas the first calvers face lactation stress and partition nutrients for continuous body growth and milk production which is in agreement to Kashoma et al. (2015). Also, this shows the same result that persistency of lactation in the first parity is higher than in the second parity but there was a lower peak milk yield in the first parity (Cho et al. 2016). However, higher daily milk yield in the first parity cows obtained during the late lactation (fig 3)might be related to the ability to gain body weight and condition in the first calvers at a late stage after full recovery from lactation stress and full mature age. In support of this, the rate of variation between $1^{\text {st }}$ and $2^{\text {nd }}$ parity (fig 5) is lower during the late than any other lactation stages.

Table 2 shows the least-squares means of first and second parity morning and afternoon lactation and daily milk yield. There was no significant difference $(\mathrm{P}>0.05)$ between the first and second parity in morning and afternoon total, 305 days lactation, and daily milk yield. These traits were also not significant during the mid and late lactation, however, the mean daily milk yield produced was only significant $(\mathrm{P}<0.05)$ between the first and second parity for the morning and afternoon during the early lactation stage, and at this stage, the daily milk yield is enhanced by $1.07 \mathrm{Kg}(13.06 \%)$ and $0.98 \mathrm{Kg}(13.57 \%)$ for parity 2 in the morning and afternoon respectively. Besides, the result presented in fig 6clearly illustrated the existence of high variation in daily milk yield for the morning and afternoon between parity 1 and 2 during the first 100 days. The total morning and afternoon lactation milk yield is decreased by 25 and $116 \mathrm{Kg}$ respectively in parity 2 which is associated with the shorter lactation length in parity 2 than parity 1 . Besides, the mean morning and afternoon late lactation daily milk yield are relatively lower in parity 2 than parity 1 which might be related to the ability to gain body weight and condition in the first calvers at a late stage after full recovery from lactation stress and full mature age. The mean daily milk in the morning increased for parity 2 on average by $29.14,26.14$, and $24.31 \%$ during early, mid, and late stage of lactation respectively, and the rate of variation(fig 5) in the daily morning milk yield between parity 1 and 2 ranges from 10$51 \%$. The mean daily milk in the afternoon is also increased for parity 2 on average by 13.93 , and $6.73 \%$ during early and mid-stage of lactation respectively but decreased on average by $5.4 \%$ during the late stage of lactation. The rate of variation in the daily afternoon milk yield between parity 1and 2 ranged from -19.73-50\% (fig 6). 
Generally, this study revealed the influence of parity on the morning and afternoon mean daily milk and showed the existence of high variation between parity 1 and 2 in the morning and afternoon mean daily milk yield.

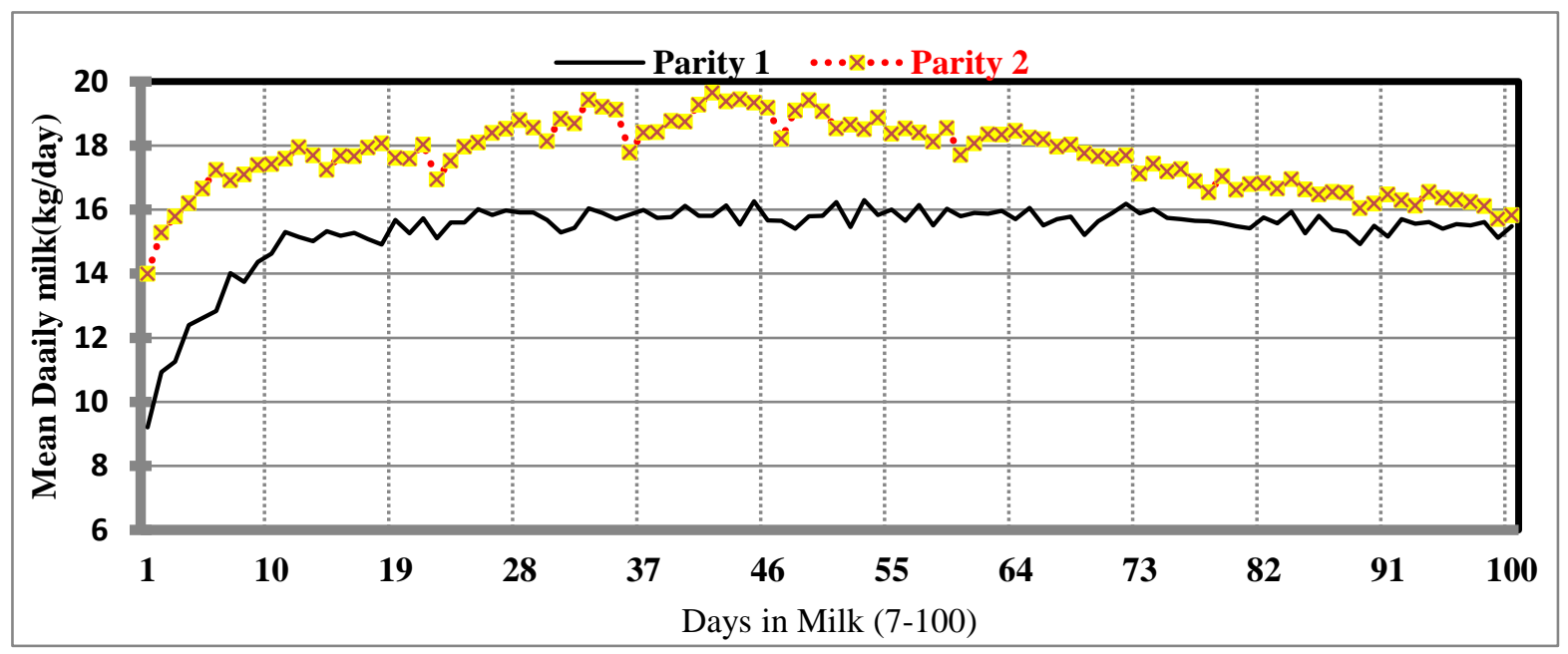

Figure 2. Lactation pattern during the early lactation stage

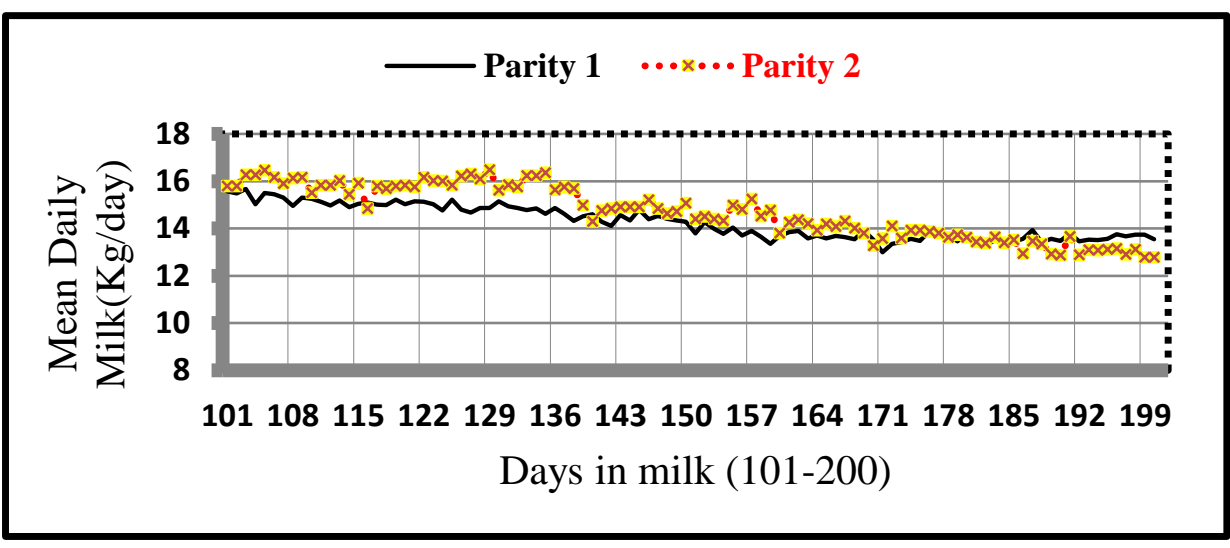

Figure 3. The pattern of milk yield during mid-lactation

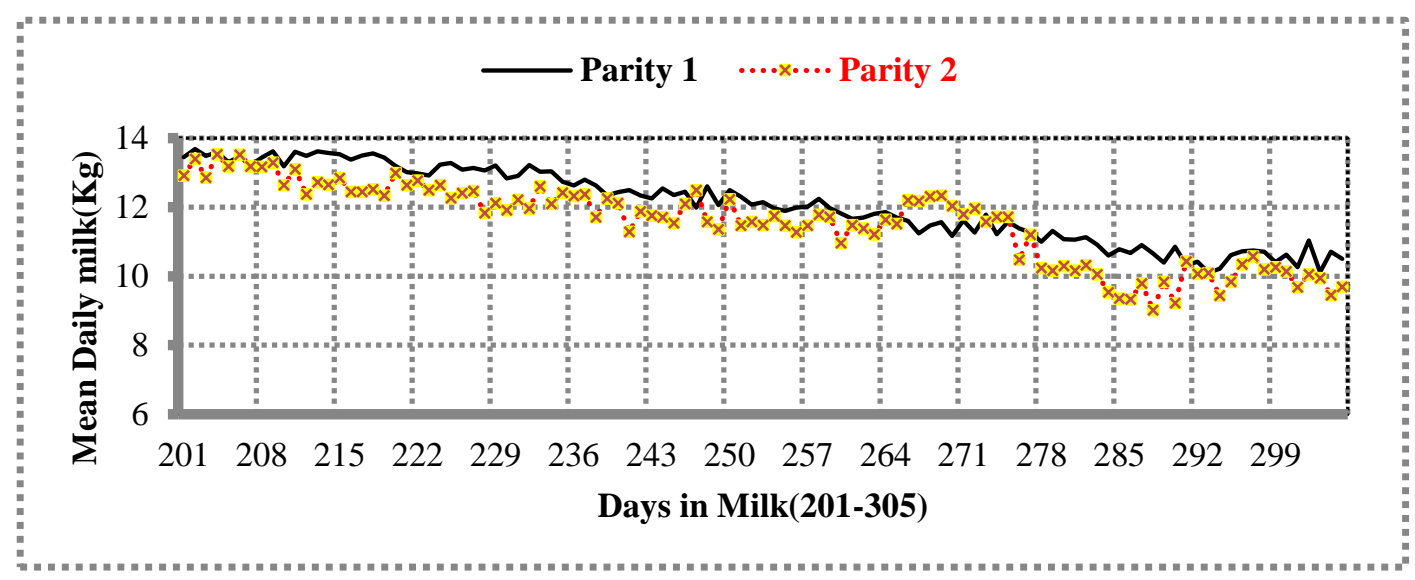

Figure 4. The pattern of lactation during the late lactation stage 


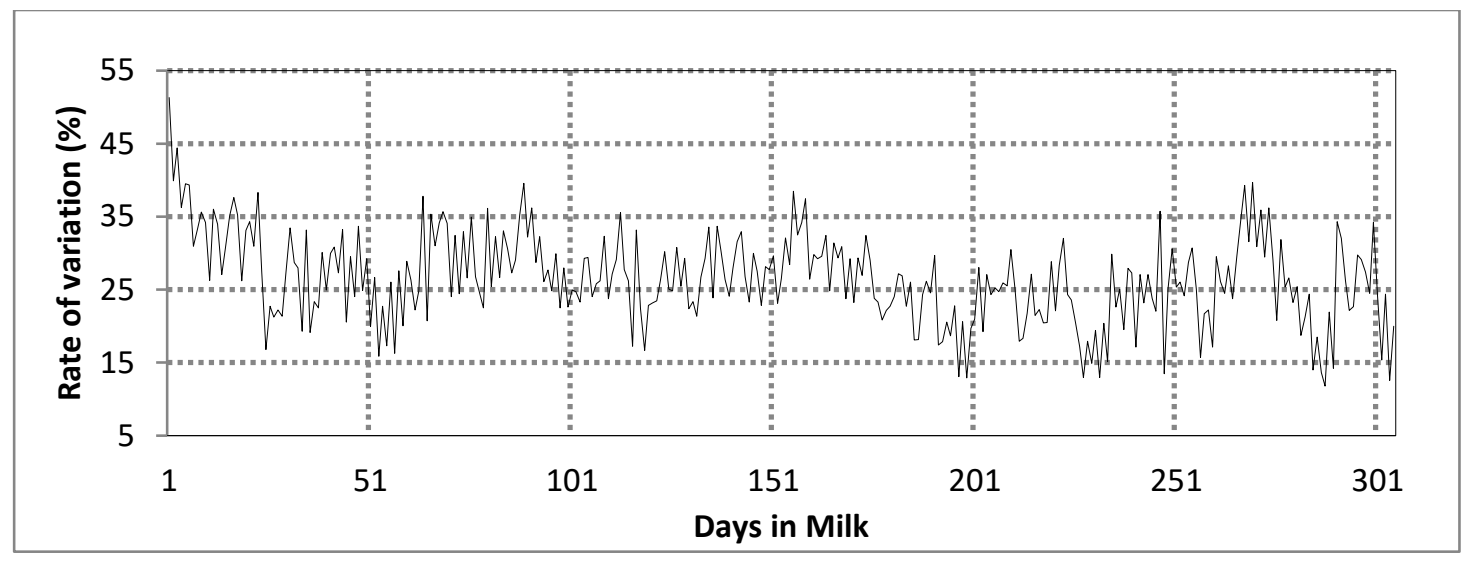

Figure 5. Rate of variations in daily morning milk yield between parities

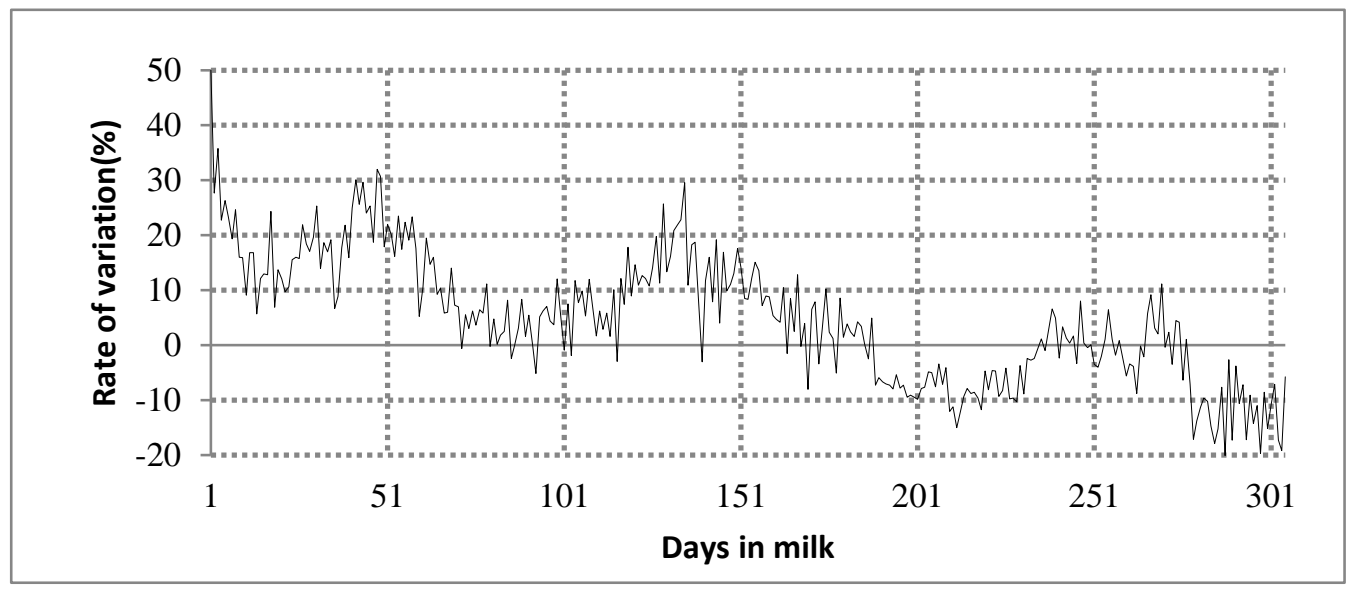

Figure 6. Rate of variations in daily afternoon milk yield between parities

\section{Conclusions}

Parity was significantly influenced the daily milk yield of lactation. Cows in the first lactation had the lowest peak yields but the highest days in milk at peak and more persistent than cows in the second lactation. Further study is required to examine additional aspects of parity on lactation traitssuch asmilk composition and reproductive traits with more lactation numbers.

Acknowledgments

The authors thank Haramaya University for financial support and the dairy farm staff of the University for practical helpduring the trial period.

Authors' contribution The first author developed the study concept and design, material preparation, data collection, and analysis, wrote the manuscript. The second author collected milk samples and did laboratory, read, and approved the final manuscript.

Conflict of interest None.

\section{References}

1) Abdel Rahman MK, Alemam TA. 2008. Reproductive and productive performance of Holstein-Friesian cattle under tropical conditions with special reference to Sudan- a review. Agricultural Reviews 29: 68 -73.

2) Amani Z, Gader A, Mohammad AK, Ahmed ML, Musa A, Peters KJ. 2007. Milk yield and reproductive performance of Friesian cows under Sudan tropical conditions. Archives Animal Breed 50:155-164.

3) Amasaib EO, Abu Nikhaila AM, FadelElseed AN, Mohamed HE (2008). Effect of season of calving and parity on some productive traits in pure and crossbred cattle in Sudan. Research Journal of Dairy Sciences 2: 5-8.

4) Arbel R, Bigun Y, Ezra E, Sturman H, Hojman D. 2001. The effect of extended calving intervals in high lactating cows on milk production and profitability. Journal of Dairy Science84:600-608. 
5) Belay D, Yisehak K., Janssens GPJ. 2012. Productive and reproductive performance of ZebuXHolstein-Friesian crossbred dairy cows in Jimma town, Oromia, Ethiopia. Global Veterinaria 8: 67-72.

6) Bytyqi H, Rrustemi M, Mehmeti H, Kryeziu A, Gjinovci V, Gjonbalaj M. 2009. Milk Production in Commercial Cattle Dairy Farms in Kosova. Journal of Animal Improvement 63: 275-285.

7) Cho CI, Alam M, Choi TJ, Choy YH, Choi JG, Lee SS, Cho KH. 2016. Models for Estimating Genetic Parameters of Milk Production Traits Using Random Regression Models in Korean Holstein Cattle. Asian-Australasian Journal of Animal Science29: 607-614.

8) Coffey MP, Hickey J, Brotherstone S. 2006. Genetic aspects of the growth of Holstein-Friesian dairy cows from birth to maturity. Journal of Dairy Science 89:322-329.

9) Dado RG, Allen MS. 1994. Variation in and relationships among feeding, chewing, and drinking variables for lactating dairy cows. Journal of Dairy Science 77:132-144.

10) Dijkstra J, France J, Dhanoa MS, Maas JA, Hanigan MD, Rook AJ, Beever D. 1997. Model to describe growth patterns of the mammary gland during pregnancy and lactation. Journal of Dairy Science 80: 2340-2354.

11) Epaphras A, Karimuribo ED, Msellem SN. 2004. Effect of season and parity on lactation of crossbred Ayrshire cows reared under coastal tropical climate in Tanzania. Livestock Research for Rural Development 16.

12) Erdem H, Atasever S, Kul E. 2007. Milk yield and fertility traits of Holstein cows raised at gokhoyuk state farm milk yield traits. Journal of Faculty of Agriculture 22: 41-46.

13) Kashoma IP, Mwingira SM, Werema CW, Kessy BM. 2015. Productive and reproductive performance of Friesian cows at Kitulo livestock multiplication unit, Tanzania. Tanzania Veterinary Journal 30: 33-41.

14) Kocak S, Yuceer B, Ugurlu M, Ozbeyaz C. 2007. Some production traits of Holstein cows reared in Bala state farm. LalahanHayvancilikArastirmaEnstitusuDergisi 47:9-14.

15) Kollalpitiya KM, Premaratne S, Peiris BL. 2012. Reproductive and Productive Performance of Up-Country Exotic Dairy Cattle Breeds of Sri Lanka. Tropical Agricultural Research 23: 319-326.

16) Krishantan G, Sinniah J. 2014. Productive and Reproductive Performance of Holstein Friesian Cattle in the Hill Country of Sri Lanka. Global Veterinaria 13: 87-94.

17) Kumar N, Alemayehu E, Abreha T, Hailelule AY. 2014. Productive performance of indigenous and Holstein-Friesian crossbred dairy cows in Gondar, Ethiopia. Veterinary World 7: 177-181.

18) Lateef M, Gondal KZ, Younas M, Sarwar M, Mustafa MI, Bashir MK. 2008. Milk Production Potential of Pure Bred Holstein Friesian and Jersey Cows in Subtropical Environment of Pakistan. Pakistan Veterinary Journal 28: 9-12.

19) Metaxas L. 2016. The Production Performance of Holstein and Fleckvieh X Holstein Cows in an Intensive Feeding System.Thesis (MSc Agric)--Stellenbosch University.

20) Ngongoni NT, Mapiye C, Mwale M, Mupeta B. 2006. Factors affecting milk production in the smallholder dairy sector of Zimbabwe. Livestock Research for Rural Development 18.

21) Ojango JM, Pollott GE. 2001. Genetics of milk yield and fertility traits in Holstein Friesian cattle on large scale Kenyan farms. Journal of Animal Sciences 79: 1742-1750.

22) Pandey GS, Voskuil GC. 2001. Manual on improved feeding of dairy cattle by smallholder farmers. Golden valley agricultural research trust Lusaka, Zambia. 50.

23) Parineeta K, Dhara P, Ashish C, Bahuguna PK, Joshi RS, Rank DN. 2017. Genetic Parameters of Production and Reproduction Traits and Factors affecting it in Frieswal Cattle. International Journal of Livestock Research 7: 190-199.

24) Rekika B, Ben Gara A, Ben Hamouda M, Hammami H. 2003. Fitting lactation curves of dairy cattle in different types of herds in Tunisia. Livestock Production Science 83: 309-315.

25) Sattar A, Mirza RH, Niazi AA, Latif M. 2005. Research Institute for Physiology of Animal Reproduction, Bhunikey (Pattoki), Distt.Kasur, Pakistan-55300.Pakistan Veterinary Journal 25.

26) Sorensen MT, Norgaard JV, Theil PK, Vestergaard M, Sejrsen K. 2006. Cell turnover and activity in mammary tissue during lactation and the dry period in dairy cows. Journal of Dairy Science 89: 4632-4639.

27) Tekerli M, Akinci Z, Dogan I., Akcan A. 2000. Factors Affecting the Shape of Lactation Curves of Holstein Cows from the Balikesir Province of Turkey. Journal of Dairy Science 83:1381-1386.

28) Usman T, Guo G, Suhail SM, Ahmed S, Qiaoxiang L, Qureshi MS, Wang Y. 2012. Performance traits study of Holstein Friesian cattle under subtropical conditions. Journal of Animal and Plant Sciences 22:92-95.

29) Wathes DC, Cheng Z, Bourne N, Taylor VJ, Coffey MP, Brotherstone S. 2007. Differences between primiparous and multiparous dairy cows in the inter-relationships between metabolic traits, milk yield, and body condition score in the periparturient period. Domestic Animal Endocrinology 33: 203-225.

30) Wondossen A, Yohannes B, Wahid MA. 2018. Productive, Reproductive Performance of Crossbred Dairy Cows in Tropical Highland, South Western, Ethiopia. Journal of Reproduction and Infertility 9: 01-08. 